Jap. J. Limnol. 42, 2, 100-107, 1981.

\title{
NOTE
}

\section{Effect of River Discharge on the Distribution Pattern of Dissolved Constituents in the Gamō Estuary, Miyagi Prefecture*}

\author{
Eisuke KIKUCHI and Yasushi KURIHARA
}

\begin{abstract}
This study reports a series of measurements of chlorinity, dissolved inorganic nitrogen, phosphate and oxygen in the Gamō estuary, a salt wedge estuary.

$\mathrm{NH}_{4}^{+}$and $\mathrm{PO}_{4}^{3-}$ concentrations of saline water in the salt wedge generally increased with the distance upstream, whereas dissolved oxygen concentration decreased with it. In addition, the development of anoxic condition and the accumulation of $\mathrm{NH}_{4}^{+}$and $\mathrm{PO}_{4}^{3-}$ were observed in the bottom saline water inside a series of basins. The strong local difference in the chemical properties was found in the deep water of basins separated by a shallow sill at the high river discharge. The results suggest that the increase of $\mathrm{NH}_{4}^{+}$and $\mathrm{PO}_{4}^{3-}$ concentration and the decrease of dissolved oxygen in the saline wedge are explained by detention time in the estuary and also indicate that the highly saline waters are generally trapped and isolated in the deeper parts of the basins by shallow sills. The phytoplankton bloom dominated by diatoms (Cyclotella) in the surface river water and the high density of ciliates (Mesodinium) immediately below the halocline were observed at the low river discharge.
\end{abstract}

\section{Introduction}

The Gamō estuary is situated about 10 $\mathrm{km}$ east of Sendai City $\left(38^{\circ} 15^{\prime} \mathrm{N}\right.$ lat., $141^{\circ} 1^{\prime} \mathrm{E}$ long.), where the Nanakita River opens into the Sendai Bay facing Pacific Ocean (Fig. 1). The Nanakita River has a length of about $45 \mathrm{~km}$ and a drainage area of $200 \mathrm{~km}^{2}$. There is a weir about $4.2 \mathrm{~km}$ upstream from the mouth. The area downstream of the weir is the usual estuarine part. The Umeda River flows into the Nanakita River just upstream of this weir. The river discharge of the Nanakita River and Umeda River accounts for about $80 \%$ and $20 \%$ of that entering the estuarine part, respectively (Hanawa and Sugimoto, 1979). Both rivers are highly polluted with domestic sewage. As a whole, this estuary has the salinity distribution of a salt wedge type (Hanaw a and Sugimoto, 1979). The aim of this study is to describe the distributions of some dissolved constituents which reflect the physical, chemical and

\footnotetext{
* Supported by a grant in aid for special project research from the Ministry of Education.
}

biological processes in the Gamō estuary with special reference to river discharge and bottom topography.

\section{Materials and Methods}

The sampling stations of water in the Gamō estuary are shown in Fig. 1. Water samples were collected with a handoperated pump from a boat. The first subsample collected from each depth was used for determination of the dissolved oxygen concentration following the method of Winkler as modified by STRICKLAND and PARsons (1972). A second subsample collected in acid-washed polyethylene bottles was filtered (Whatman GF/C glass-fiber filter) and frozen. Frozen samples were thawed and analyzed for ammonium, nitrate, nitrite and phosphate following methods outlined by STRICKLAND and PARSONS (1972). A third subsample was drawn for chlorinity determination. Chlorinity was determined by silver nitrate titration. A fourth subsample was preserved with $5 \%$ formalin for examination of plankton. 


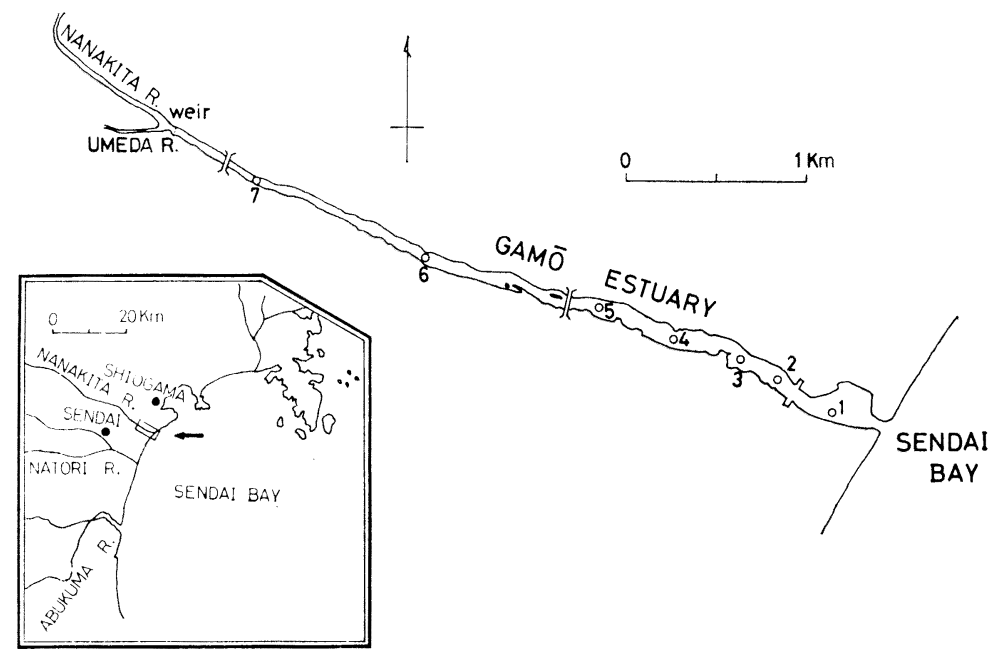

Fig. 1. Station position in the Gamō estuary.

\section{Results and Discussions}

\section{Longitudinal distributions of dissolved constituents in moderate river discharge}

The longitudinal distributions of dissolved constituents on 6 July 1976 (river discharge, $3 \mathrm{~m}^{3} / \mathrm{sec}$ ) are shown in Fig. 2. River discharges were estimated from Q-H curve according to Hanawa and Sugimoto (1979). Water samples of st. 1, 3, 5, 6 and 7 were taken at flood tide, and water samples of only st. 4 were taken at ebb tide. Thus, it seems that Fig. 2 indicated the rough distribution of dissolved constituents at a flood tide. There was an intrusion of a saline wedge along the bottom, bounded by a sharp halocline of up to $15 \%$ (chlorinity) in less than $0.5 \mathrm{~m}$, from the fresh river water on the surface (Fig. 2-(a)). The salt wedge penetrated up to the weir, $4.2 \mathrm{~km}$ upstream from the mouth. The chlorinity of saline water entering the estuary along the bottom was not different from that of sea water. The chlorinity in the salt wedge decreased a little from the mouth to the wedge tip, and the salt water was slightly entrained by the surface freshwater.

The concentrations of $\mathrm{NO}_{3}^{-}$were considerably higher in the surface river water than in the saline water of the salt wedge. The concentration markedly decreased with the increase of chlorinity in the halocline

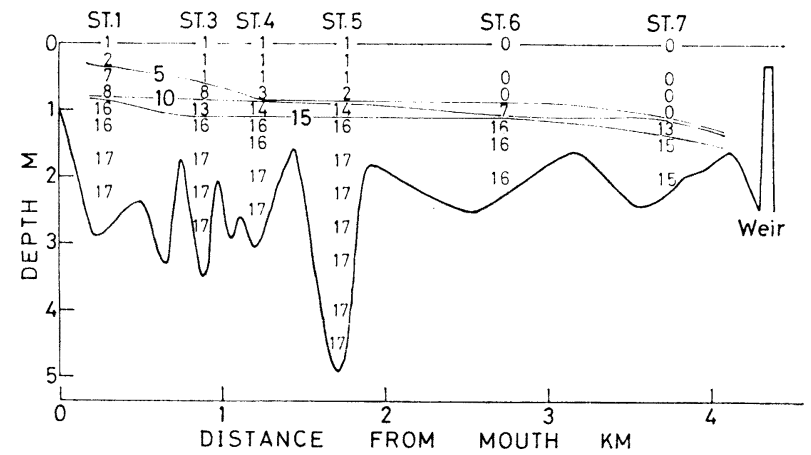

Fig. 2-(a). Bathymetric profile of the Gamō estuary and longitudinal distribution of chlorinity $(\%)$ at the moderate river discharge on 6 July 1976. 


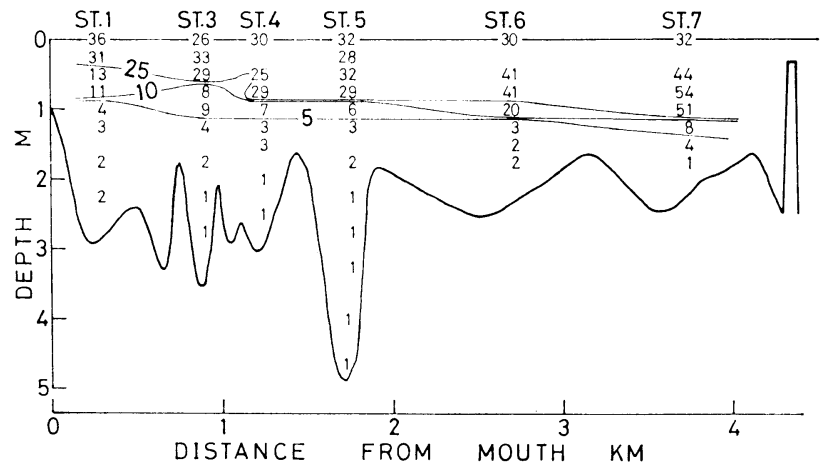

Fig. 2-(b). Longitudinal distribution of $\mathrm{NO}_{3}^{-}-\mathrm{N}(\mu \mathrm{g}-\mathrm{at} / l)$ at the moderate river discharge on 6 July 1976.

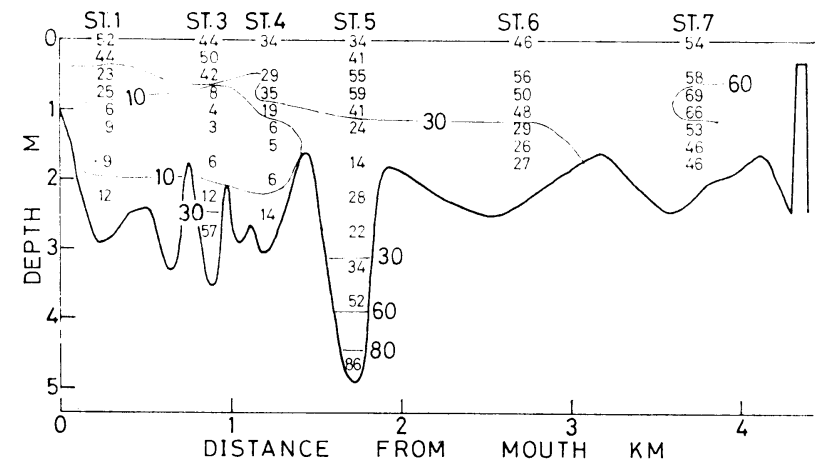

Fig. 2-(c). Longitudinal distribution of $\mathrm{NH}_{4}^{+}-\mathrm{N}(\mu \mathrm{g}-\mathrm{at} / \mathrm{l})$ at the moderate river discharge on 6 July 1976.

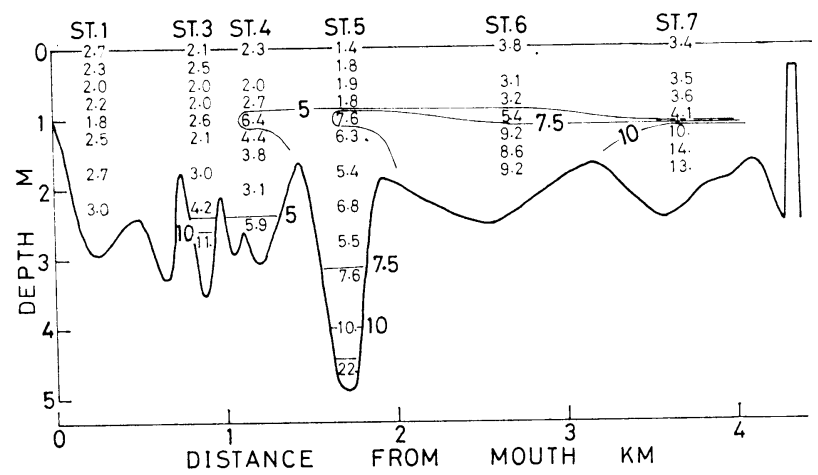

Fig. 2-(d). Longitudinal distribution of $\mathrm{PO}_{4}^{3-}-\mathrm{P}(\mu \mathrm{g}-\mathrm{at} / l)$ at the moderate river discharge on 6 July 1976. 


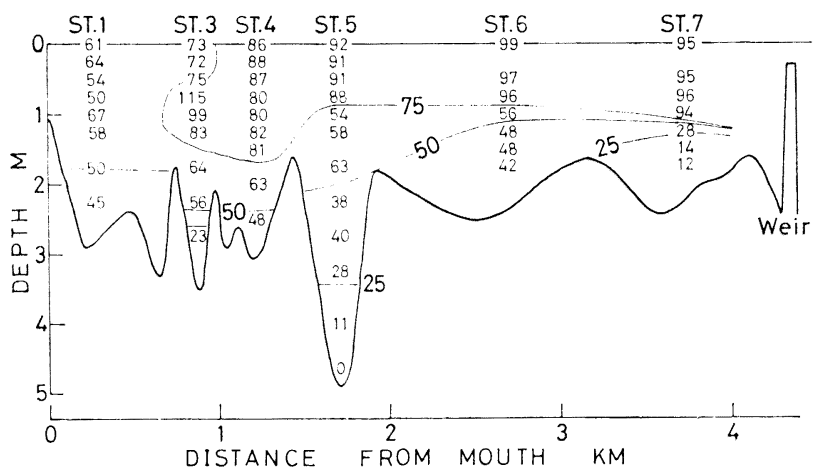

Fig. 2-(e). Longitudinal distribution of dissolved oxygen $(\%)$ at the moderate river discharge on 6 July 1976. .

(Fig. 2-(b)). The concentration of $\mathrm{NO}_{3}^{-}$in sea water was much lower than in the river water (Table 1 ). These results suggest that the concentration of $\mathrm{NO}_{3}^{-}$is determined by the dilution of the river water by the sea water.

The concentrations of $\mathrm{NH}_{4}^{+}$and $\mathrm{PO}_{4}^{3-}$ in the surface river water were fairly uniform along the transect, while those in the saline water of salt wedge markedly increased to the wedge tip and with the depth especially inside the deep basins (Fig. 2-(c) and (d)). However, the chlorinity varied little from the wedge tip to the estuary mouth and with depth within the salt wedge (Fig. 2(a)). Unlike $\mathrm{NH}_{4}^{+}$and $\mathrm{PO}_{4}^{3-}$, the dissolved oxygen in the sat wedge markedly decreased to the wedge tip and with the depth. The concentrations of $\mathrm{NH}_{4}^{+}$and $\mathrm{PO}_{4}^{3-}$ in sea water entering the estuary were lower and the concentrations of dissolved oxygen in sea water were higher than those of the saline water of the wedge tip and the deep water inside the basins. It is known that in the deeper parts of several estuaries and fjords, shallow sills have restricted the circulation of water and the resulting salinity-dominated stability profile leaves the deep saline water stagnant and allows the development of anoxic condition and the accumulation of $\mathrm{NH}_{4}^{+}$and $\mathrm{PO}_{4}^{3-}$ (DAYER and RAMAMOORTHY, 1968 ; RichARDS et al., 1971; GAIN and PILSON, 1972 ; WELCH et al., 1972). In addition, the detention time of saline water within the wedge increases from the estuarine mouth to the wedge tip. Therefore, our results suggest that the concentrations of $\mathrm{NH}_{4}^{+}$and $\mathrm{PO}_{4}^{3-}$ in saline water increase and that of dissolved oxygen decreases with the increase of detention time in the estuary as the result of the decomposition of organic matter in the water and sediment. As for the distribution of dissolved oxygen, a similar result was obtained by FRANKENBERG (1976) in the

Table 1. The chlorinity and the concentrations of dissolved oxygen, ammonia, nitrate, nitrite, and phosphate in the sea water which penetrated upstream through the mouth at a flood tide (1000 hours) and in the river water $(5 \mathrm{~km}$ upstream from the mouth) at 1000 hours on 6 July 1976.

\begin{tabular}{lcccccc}
\hline & chlorinity $(\%)$ & $\mathrm{DO}(\%)$ & $\mathrm{NH}_{4}^{+}-\mathrm{N}^{*}$ & $\mathrm{NO}_{3}^{-}-\mathrm{N}^{*}$ & $\mathrm{NO}_{2}^{-}-\mathrm{N}^{*}$ & $\mathrm{PO}_{4}^{3-}-\mathrm{P}^{*}$ \\
\hline Sea water & 17.6 & 96 & 0.1 & 1.0 & 0.1 & 0.3 \\
Umeda river & 0.2 & 100 & 79 & 56 & 6.2 & 5.3 \\
Nanakita river & 0.2 & 93 & 25 & 31 & 1.8 & 2.4 \\
\hline
\end{tabular}

* $\mu \mathrm{g}-\mathrm{at} / l$ 
Duplin River, Georgia, a logoon-type tidal river.

Figure 3 shows the vertical distributions of dissolved constituents of st. 5 at flood and ebb tide. There was little difference in the vertical distributions of dissolved constituents between flood tide and ebb tide. Hanawa and Sugimoto (1979) reported that the salinity variations induced by the tide throughout the salt wedge are negligible in the Gamō estuary, and the tide
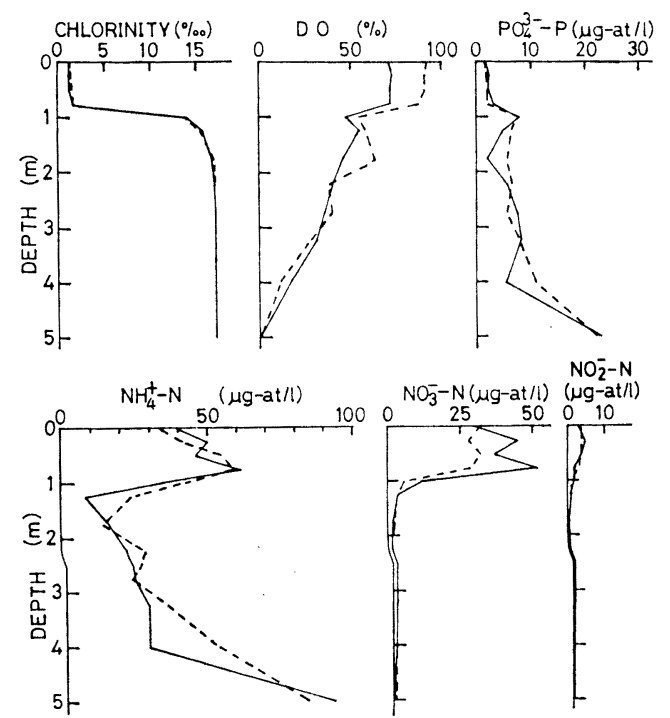

Fig. 3. Vertical distributions of dissolved constituents at st. 5 (2.7 km upstream from the mouth) on 6 July 1976.

- flood tide 1000 hours)

-----ebb tide (1400 hours).

influences only the thickness and the salinity distribution near the mouth. These results suggest that the effect of the tide on the distribution of dissolved constituents was almost negligible in the estuary except near the mouth area. The behaviour of dissolved matter near the mouth with tidal cycle awaits further study.

2. The longitudinal distributions of dissolved constituents in the high river discharge

Figure 4 shows the distribution of dissolved constituents at flood tide on 19 August 1976 (river discharge, $15 \mathrm{~m}^{3} / \mathrm{sec}$ ). The saline water penetrated along the bottom up to $1 \mathrm{~km}$ from the mouth and the halocline was present at the depth below $2 \mathrm{~m}$. The chlorinity of water within the salt wedge increased with the depth. The chlorinity of bottom water in the basins $(8-11 \%)$ was lower than that of sea water, indicating that the sea water within the salt wedge was diluted considerably by river water. Hanawa and Sugimoto (1979) reported that in the high river discharge, the sea water just outside of the mouth, which had already been diluted considerably with river water, flowed into the Gamō estuary at flood tide. They estimated that the limit of the river discharge which is able to prevent the intrusion of the salt wedge into the estuary is about $30 \mathrm{~m}^{3} / \mathrm{sec}$. The strong differences in the chemical properties were found in the deep layer between two basins, st. 2 and st. 3 , being separated by a shallow sill. At st. 2, a basin nearer to the mouth, the concentrations of $\mathrm{NO}_{3}^{-}, \mathrm{NH}_{4}^{+}$and $\mathrm{PO}_{4}^{3-}$ of deep saline water were lower than those of fresh river water, suggesting the recent infiltration of seawater diluted with river water. However, in the deep water of st. 3 , the concentration of $\mathrm{NH}_{4}^{+}$was higher and that of dissolved oxygen was lower than those of the surface river water. This result suggests that the deep saline water of st. 3 was trapped and isolated by a shallow sill for a relatively long period. Thus, $\mathrm{NH}_{4}^{+}$was accumulated and dissolved oxygen was consumed by decomposition of organic matter in the water and sediment. The $\mathrm{NO}_{3}^{-}$concentrations in saline waters at both st. 2 and st. 3 decreased with increasing chlorinity. The linearity in the $\mathrm{NO}_{3}$ chlorinity relationship (Fig. 5) indicates the concentration of $\mathrm{NO}_{3}^{-}$might be determined by the dilution of river water with seawater.

3. Vertical distributions of dissolved constituents after the long-term low river discharge

Figures 6 and 7 show the vertical distributions of dissolved constituents and plankton at st. 5 on 21 August 1975 (river discharge, less than $0.1 \mathrm{~m}^{3} / \mathrm{sec}$ ). There was little rainfall in August 1975. The 
(a) CHLORINITY, \%。

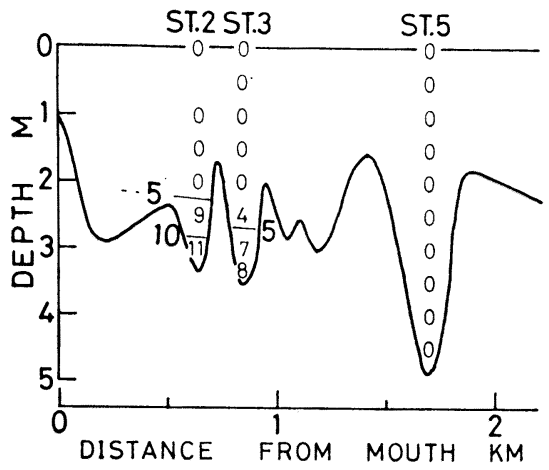

(c) $\mathrm{NH}_{4}^{+}-\mathrm{N}, \mu \mathrm{g}-\mathrm{at} / \mathrm{l}$

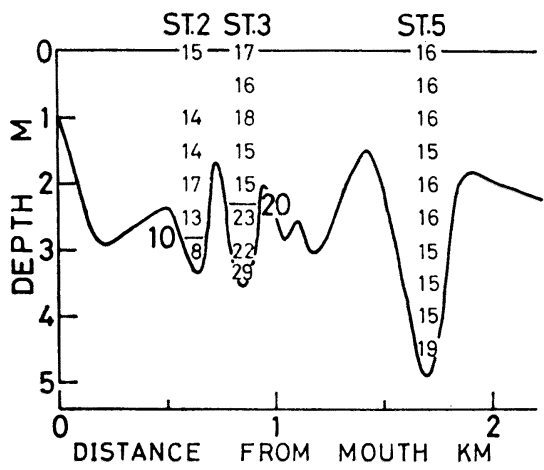

(e) DISSOLVED OXYGEN, \%

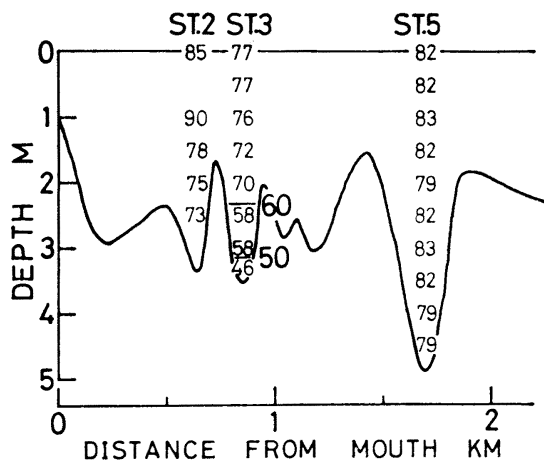

(b) $\mathrm{NO}_{3}^{-}-\mathrm{N}, \mu \mathrm{g}-\mathrm{at} / \mathrm{l}$

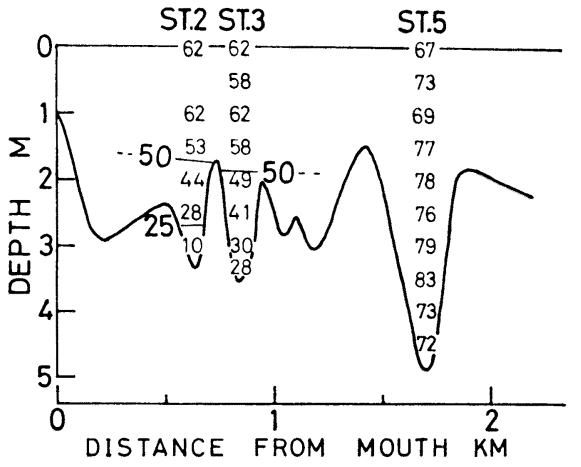

(d) $\mathrm{PO}_{4}^{3-}-\mathrm{P}, \mu \mathrm{g}-\mathrm{at} / \mathrm{l}$

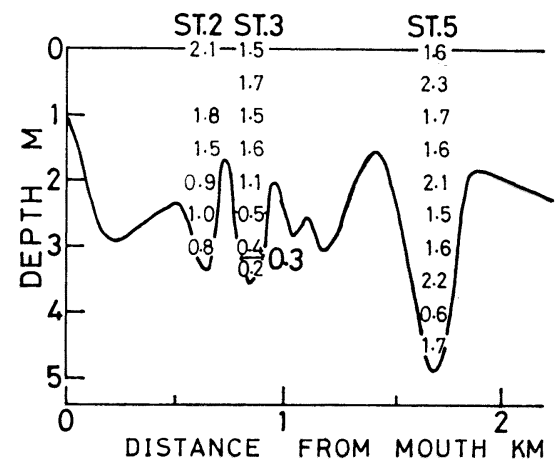

Fig. 4. Longitudinal distribution of (a) chlorinity, (b) $\mathrm{NO}_{3}^{-}-\mathrm{N}$, (c) $\mathrm{NH}_{4}^{+}-\mathrm{N}$, (d) $\mathrm{PO}_{4}^{3-}-\mathrm{P}$ and (e) dissolved oxygen at the high river discharge on 19 August 1976.

vertical distribution of chlorinity shows that the strong halocline was present at the depth from $0.5 \mathrm{~m}$ to $0.75 \mathrm{~m}$ at low water (0930 hours). This halocline was pushed upwards until it reached the surface at high water (1600 hours), indicating that the development of a saline wedge pushed the river water upstream and impounded it in the upper estuary. The chlorinity of the surface river water was about $6 \%$. This indicates the river water entrained the saline water of the wedge and the distribution of chlorinity was similar to the near-partially mixed estuary. 


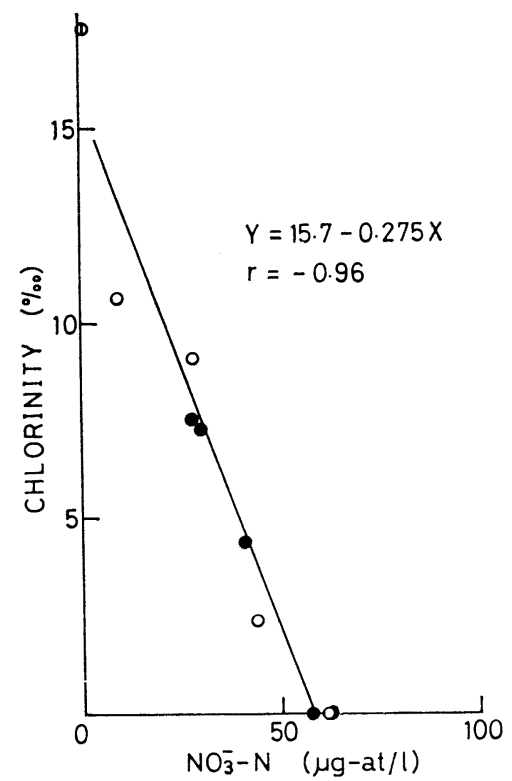

Fig. 5. Relationship between nitrate concentration and chlorinity at the high river discharge on 19 August 1976.

st. $2 \bigcirc$, st. 3 , seawater (1).

The most striking characteristics of the vertical distribution of dissolved constituents were the very high concentration of dissolved oxygen in the surface brackish river water and its very low concentration of $\mathrm{NH}_{4}^{+}, \mathrm{NO}_{3}^{-}$and $\mathrm{PO}_{4}^{3-}$. In the brackish surface water, the phytoplankton bloom dominated by diatoms, Cyclotella atomus and Cyclotella meneghiniana, was also

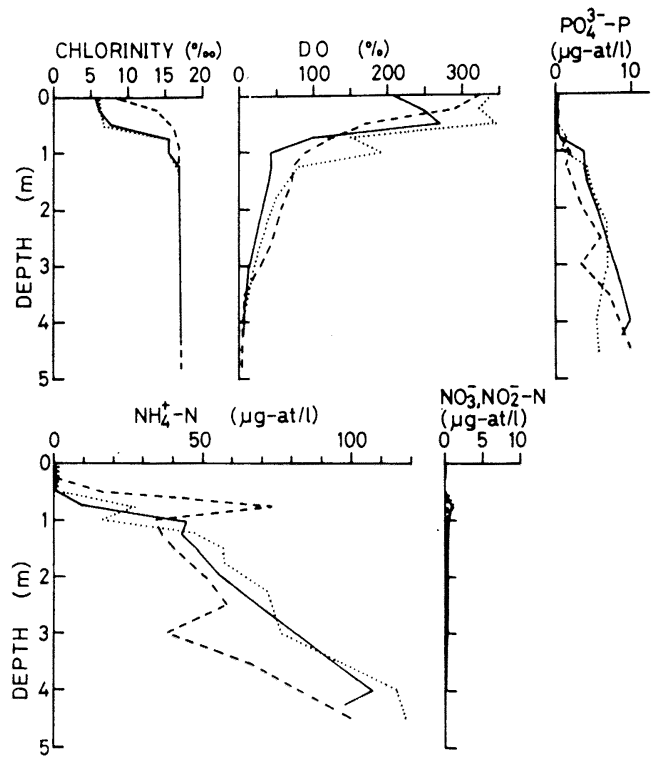

Fig. 6. Vertical distributions of dissolved constituents at st. 5 on 21 August 1975 after the long duration of the low river discharge. - low water (0930 hours), -...-.-.-flood tide (1300 hours), ----high water (1600 hours).

observed. This indicates that the very high concentration of dissolved oxygen and the very low concentrations of $\mathrm{NH}_{4}^{+}, \mathrm{PO}_{4}^{3-}$ and $\mathrm{NO}_{3}^{-}$in the surface river water were caused by the production of dissolved oxygen and comsumption of $\mathrm{NH}_{4}^{+}, \mathrm{PO}_{4}^{3-}$ and $\mathrm{NO}_{3}^{-}$by the phytoplankton. The low river discharge in summer may maximize the detention

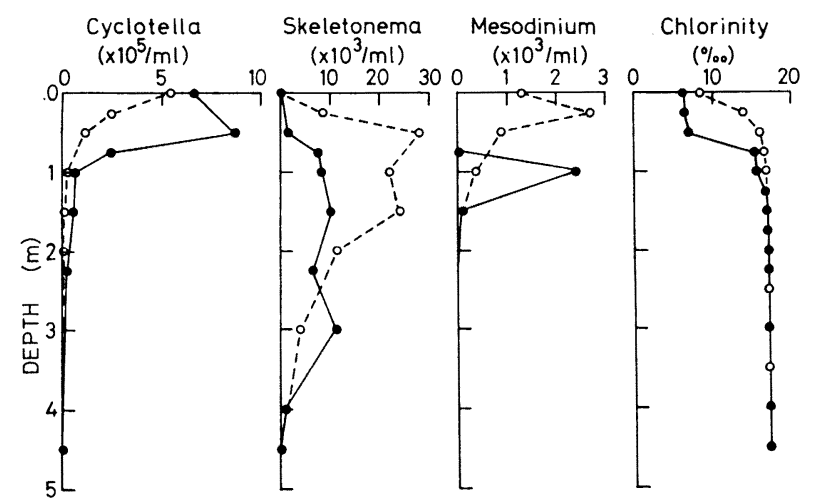

Fig. 7. The vertical distributions of plankton at st. 5 in the low river discharge on 21 August 1975. - - flood tide (1300 hours), -- $\bigcirc--$ high water (1600 hours). 
time of the river water in the river and estuary, and allow time for a number of cell divisions sufficient to produce a bloom. The saline layer below the halocline was characterized by the rapid vertical decrease in dissolved oxygen and the vertical increase in $\mathrm{PO}_{4}^{3-}$ and $\mathrm{NH}_{4}$ with depth. As for phytoplankton, Skeletonema sp. occurred below the halocline. It is noticeable that a large number of Mesodinium sp. was observed immediately below the halocline. Our survey also revealed that $1.6 \times 10^{5}$ per $\mathrm{m} l$ of Cyclotella spp. occurred in the fresh river water at $6 \mathrm{~km}$ upstream from the mouth and $2.8 \times 10^{4}$ per $\mathrm{ml}$ of Skeletonema sp. occurred in the sea water which penetrated the mouth. This suggests Cyclotella spp. and Skeletonema sp. were derived from river and sea water, respectively. Mesodinium sp. was not observed in either sea or river water. The low river discharge tended to maximize the detention time of saline water within the wedge as well as the distance the salt wedge penetrated the estuary. Consequently, Mesodinium sp. was allowed to grow and accumulate at the upper part of the salt wedge in the estuary.

\section{摘要}

仙台㴒に注ぐ七北田川の下流化位置する蒲生河口域 において, 水体中の溶存物質 (塩素量, 溶存酸素, $\left.\mathrm{NO}_{3}^{-}, \mathrm{NH}_{4}^{+}, \mathrm{PO}_{4}^{3-}\right)$ の濃度分布と河川流量および河 川地形との関係を調べた。

1. 浦生河口域は, 河川水上海水々招はとんど混し らず上下二㟄をなす塩水楔型（二層流型）の河口域で ある.

2. 下首塩水部の $\mathrm{NH}_{4}^{+}, \mathrm{PO}_{4}^{3-}$ 濃度は上流にいくほ

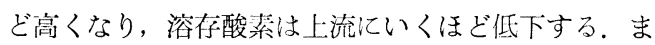
た，河底地形の凹部には，高塩分濃度の塩水が㴖留し， 塩水中の $\mathrm{NH}_{4}^{+}, \mathrm{PO}_{4}^{3-}$ 漲度は, 底部へいくにつれて增 加し, 溶存酸素は減少する.
3. 1975 年 8 月には，低河川流量の日が続き，河 川水部では，植物プランクトン (Cyclotella) が大量 に增殖し, $\mathrm{NH}_{4}^{+}, \mathrm{PO}_{4}^{3-}, \mathrm{NO}_{3}^{-}$浱度は極めて低下し, 溶存酸素濃度は過飽和となった。 また，塩水躍風直下 には䌦毛虫 (Mesodinium) が出現した。

4. 河川流量が増加すると, 河口域部に滞留する塩 水は海へ吐出され，塩水楔の長さが短くなるとともに， 塩水楔内の水塊の塩分漕度が低下する。

\section{References}

Dyer, K. R. and K. Ramamoorthy (1969) : Salinity and water circulation in the Vellar estuary. Limnol. Oceanogr., 14: 4-15.

FrankENBERG, D. (1976) : Oxygen in a tidal river: low tide concentration correlates linearly with location. Estuarine Coastal Mar. Sci., 4: $455-460$.

Gaines, A. G. and M.E. Q. Pilson (1972): Anoxic water in the Pettaquamscutt river. Limnol. Oceanogr., 17: 42-49.

Hanawa, K. and T. Sugrmoto (1979): Effect of the variation of river discharge on flushing and recovery of salt wedge (1). Sci. Rep. Tohoku Univ. Ser. 5, Geophys., 25: 219-240.

Richards, F. A., J. J. Anderson and D. C. Cline (1971) : Chemical and physical observations in Golfo Dulce, an anoxic basin on the Pacific Coast of Costa Rica. Limnol. Oceanogr., 16: 43-50.

Strickland, J.D. H. and T. R. Parsons (1972) $: A$ Practical Handbook of Seawater Analysis, 2nd edition. Bull. Fish. Res. Bd. Can. 167.

Welch, E. B., R. M. Emery, R. I. Matsuda and W. A. Dawson (1972): The relation of periphytic and planktonic algal growth in an estuary to hydrographic factors. Limnol. Oceanogr., 17: 731-737.

(著者: 菊地永祐 - 栗原康, 東北大学理学部, 干980 仙台市荒巻青葉; Eisuke KIKUCH and Yasushi Kurihara, Biological Institute, Faculty of Science, Tohoku University, Aoba, Aramaki, Sendai 980)

Accepted: 6 October 1980 